\title{
Türkiye'de Sosyal ve Dijital Girişimcilik: Veri Kazıma Teknikleriyle Kitle Fonlaması Platformlarının İçerik Analizi
}

\section{Social and Digital Entrepreneurship in Turkey: Content Analysis of Crowdfunding Platforms with Data Scraping Techniques}

\author{
Murat Kılınç ${ }^{10}$, Can Aydın² (D, Çiğdem Tarhan³ (I)
}

' (Öğr. Gör.), Manisa Celal Bayar Üniversitesi, Bilgisayar Araştırma ve Uygulama Merkezi, Manisa,Türkiye

${ }^{2}$ (Doç. Dr.), Dokuz Eylül Üniversitesi, Yönetim Bilişim Sistemleri Bölümü, Kalite ve Mükemmellik Uygulama ve Araştırma Merkezi (DEÜ-KALMER), İzmir, Türkiye

${ }^{3}$ (Doç. Dr.), Dokuz Eylül Üniversitesi, Yönetim Bilişim Sistemleri Bölümü, Bölgesel Kalkınma ve İşletme Bilimleri Araştırma ve Uygulama Merkezi (DEÜ-BIMER), İzmir, Türkiye

ORCID: M.K. 0000-0003-4092-5967; C.A. 0000-0002-0133-9634;

C..T. $0000-0002-5891-0635$

\section{Corresponding author:}

Murat KILINÇ

Manisa Celal Bayar Üniversitesi, Bilgisayar

Araştırma ve Uygulama Merkezi, Manisa,Türkiye

E-mail address: kilinc.murat@cbu.edu.tr

Submitted: 19.09 .2021

Accepted: 24.01.2022

Published Online: 02.03 .2022

Citation: Kilinc, M., Aydin, C. \& Tarhan, C. (2022). Türkiye'de sosyal ve dijital girişismcilik: Veri kazıma teknikleriyle kitle fonlaması platformlarının içerik analizi. Acta Infologica. Advance online publication.

https://doi.org/10.26650/acin.997640
ÖZ

Dijitalleşen dünyada yeni nesil girişimcilik modeli olarak sunulan kitle fonlaması (KF) modeli iş fikirlerinin gerçekleştirilebilmesi noktasında büyük fayda sağlamaktadır. Zamanla kullanıı ilgisinin artmasıyla birlikte popülerleşen KF için yurtdışında olduğu gibi Türkiye'de de birçok platform kurulmuştur. Kurulan web platformlarında toplanan fonların proje oluşturucuları tarafından kullanılabilmesi, projenin başarı durumuna bağlıdır. Projelerin başarısı KF ekosistemi için önemli bir yere sahip olduğundan dolayı, çalışma içerisinde platformlara göre başarı analizi yapılarak kategoriye göre dağılımlar, fonlamaya göre dağılımlar, özniteliklere göre dağılımlar, konumlara göre dağılımlar ortaya koyulmuştur. Bu doğrultuda,Türkiye'de faaliyet gösteren Fongogo, Crowdfon, Buluşum, Fonbulucu, Arıkovanı, Ideanest platformlarındaki 1635 KF projesi, öznitelikleri ve meta alanlarılla birlikte veri kazıma teknikleriyle toplanıp içerik analizi yöntemi kullanılarak incelenmiştir. Çalışmanın sonuçlarına göre, yaklaşık 21 milyon TL'lik bir değere sahip olan Türkiye'deki kitle fonlaması ekosisteminde proje kampanyalarının bașarı oranı $\% 23,18$ 'tir. Projeler en çok teknoloji, kültür-sanat ve filmvideo-fotoğraf kategorilerinde yayınlanmakta olup en başarılı kategori \%34,36 ile film-video-fotoğraf kategorisidir. Projeler konumlarına göre değerlendirildiğinde, en başarılı bölge $\% 30,25$ başarı yüzdesiyle Marmara bölgesidir. Ayrıca destekçiler bir projenin gerçekleştirilebilmesi için ortalama 530 TL fon sağlamaktadır ve başarılı proje başına yaklaşık olarak 55.000 TL fon düşmektedir. Elde edilen bulgular Türkiye'deki KF platformlarındaki proje ve kullanıcı sayısının geçmişe göre arttığını fakat başarı oranının gözle görülür bir biçimde düştüğünü göstermektedir. Bu nedenle KF platformları için öneriler çalışma içerisinde tartışılmıştır. Anahtar kelimeler: Kitle Fonlaması, Veri Kazıma, İçerik Analizi, Girişimcilik

\section{ABSTRACT}

The crowdfunding (CF) model, which is presented as a new generation entrepreneurship model in the digitalizing world, provides great benefits in realizing business ideas. Many platforms have been established in Turkey as well as abroad for CF, which has become popular with the increase in user interest over time. The use of the funds collected on the established web platforms by the project creators depends on the success of the project. Since the success of the projects has an important place for the CF ecosystem, the distributions by category, distribution by funding, distribution by attributes, distributions according to locations were revealed by performing a success analysis according to platforms in the study. In this direction, the 1635 CF projects operating in Turkey on Fongogo, Crowdfon, Buluşum, Fonbulucu, Arıkovanı, Ideanest platforms, together with their features and meta fields, were collected using data scraping techniques and analyzed using content analysis method. According to the results of the study, the success rate of project campaigns in the crowdfunding ecosystem in Turkey, which has a value of approximately 21 million TL, is $23.18 \%$. The projects are mostly published in the categories of technology, cultureart and film-video-photo, with the most successful category being the category of film-video-photo with $34.36 \%$. When the projects are evaluated according to their locations, the most successful region is the Marmara region with a success rate of $30.25 \%$. In addition, supporters provide an average of $530 \mathrm{TL}$ in funds for the realization of a project, and approximately 55,000 TL in funds per successful project. The findings show that the number of projects and users on CF platforms in Turkey has increased compared to the past, but the success rate has decreased noticeably. Therefore, recommendations for CF platforms are discussed in the study. Keywords: Crowdfunding, Data Scraping, Content Analysis, Entrepreneurship 


\section{GIRİŞ}

Bilişim teknolojilerinin kullanımının yaygınlaşmasıyla birlikte son zamanlarda birçok sektördeki faaliyetler dijital bir şekilde dönüştürülerek etki alanını genişletmiştir. Girişimcilik ekosisteminin bir parçası olan kitle fonlaması da bu etki alanı içerisinde yer almaktadır. Kitle fonlaması (KF), projelerini gerçekleştirmek için fikirlerin internet üzerinden destekçilere sunulmasıyla geleneksel girişimciliğin problemlerini hafifleten teknoloji temelli kaynak yaratma ve fonlama sistemidir (Cumming ve ark., 2021; Petruzzelli ve ark., 2019; Sidiq ve ark., 2021). Web 2.0 teknolojilerinin etkisini arttırması ve sosyal girişimciliğin kabul görmesiyle birlikte desteklenen KF, büyük ölçeklerde genişleyerek milyonlarca kişiye ulaşacak altyapıyı sağlamıştır (Moysidou ve Hausberg, 2020). Bu sayede kullanım amacını genişleten KF, fikirlerini gerçekleştirmek isteyen kullanıcılar için popüler bir konumdadır. Bunun yanı sıra dünya genelindeki sosyal girişimciler de ortaya koymuş oldukları girişimlerinin kontrolünü elinde tutarken finansal kısıtlamaları kaldırmak veya azaltabilmek için KF platformlarını tercih etmektedir. (Farhoud ve ark., 2021). Çünkü girişimcilerin karşılaştığı en önemli kısıtlamalardan biri finansman eksikliğidir. Bir girişim oluşturmak ve büyütebilmek için iç ve diş finansman gereklidir (Walthoff-Borm ve ark., 2018). Bu doğrultuda, geçmişte geleneksel olarak yeni bir fikri olan ve finansman ihtiyacı duyan girişimciler banka kredisi ve risk sermayesi yatırımcılarıyla finansal gereksinimlerini sağlayabiliyordu. KF platformları tam da bu noktada ek bir unsur olarak ortaya çıkarak girişimciler için yeni bir finansman kaynağı oluşturmaktadır (Babich ve ark., 2020). Bu kaynaklarla birlikte, özellikle son 10-15 yıl içerisinde birçok iş fikri ulaşılabilir bir şekilde tasarlanan web tabanlı KF platformları üzerinden toplanan fonlarla hayata geçmiştir. Kitlelerden gelen finansmanla birlikte oluşturulan proje sayısı da büyük bir artış göstermektedir. Öyle ki yalnızca 2020 yılında yaklaşık olarak 6,5 milyon KF kampanyası platformlarda yer almıştır. Kampanyaların platformlardan topladı̆̆ miktarı ise bir önceki yıla göre yaklaşık \%33’lük bir artış göstermiştir (Fundera, 2021). Bu doğrultuda ortaya koyulan istatistikler, yakın gelecekte dünya genelindeki KF ekosistemin büyümesini öngörmektedir. Yapılan pazar analizleri de küresel kitle fonlamasının 2021'den 2025'e kadar potansiyel olarak 196 milyar dolar büyüyebileceğini ortaya koymakta ve büyümenin \%62'sinin Asya-Pasifik ülkelerinden gelmesini beklemektedir. (Chang, 2021).

Türkiye'de ise KF finansmanının kullanımı, projelerin hayata geçirilmesi ve web platformlarının işlevselliği gelişim aşamasındadır. 2013 yılı sonrasında platform sayısındaki artışla beraber bir hareketlenme durumu söz konusu olmuştur. Fakat Türkiye'de diğer türlerle kıyaslandığında (bağış tabanlı, paya dayalı) ödül tabanlı KF platformlarının kullanımı daha yaygındır. Çünkü ödül tabanlı KF harici türlerde yasal sebepler ve yakın zamana kadar mevzuat olmayışı bu durumu zorunlu k1lmıştır (Çonkar ve Canbaz, 2018). Günümüzde ise gerekli düzenlemelerle birlikte faaliyet gösterilebilen KF türü sayısı Türkiye'de artmıştır. Bu doğrultuda, ödül tabanlı, bağış tabanlı ve paya dayalı KF platformları faaliyetlerini sürdürmektedir. Yani, ilerleyen zaman dilimlerinde bağış tabanlı ve paya dayalı platformlardaki proje sayılarının da artış göstermesi beklenmektedir. Borç tabanlı platformlar ise henüz Türkiye'de uygulanmamaktadır.

Diğer taraftan, Türkiye'deki KF platformlarına olan ilgi geçtiğimiz yıllara göre artmış olsa da başarı oranı gözle görülür bir biçimde azalış eğilimi göstermektedir. KF platformlarıly ilgili yapılan bir araştırmaya göre 2017'de KF başarı oranı \%30 olarak belirtilmiştir (Çubukçu, 2017). Yine benzer bir araştırmada, 2018 yılında Türkiye'deki KF platformlarındaki başarı oranı \%29,18 olarak belirtilmiştir (Çonkar ve Canbaz, 2018). 2021 yılına gelindiğinde ise proje sayısı yaklaşık 3-4 katına çıkmış fakat başarı oranı çalışmamızdaki veriler baz alındığında \%23,18 oranına gerilemiştir. Bu gerilemenin sebepleri platformların proje oluşturucuları tarafından kullanışlı bulunamaması ve projelerin yeterince iyi hazırlanmadan veya yanlış meta verileriyle destekçilere sunulmasıdır (Kayhan, 2017). Dolayısıyla, KF platformlarında başarısız proje sayısının artması somut olarak kitle fonlamasını, girişimcilik ekosistemini ve katma değer oluşmasını olumsuz etkilemektedir. Çok iyi iş fikirleri ya da kampanyalar bile iyi hazırlanıp sunulmadığı için gerekli fonu alamamaktadır. Bu doğrultuda, başarısız olan her proje kalitesizdir anlamına gelmemektedir. Tam aksine, bazı projeler yaratıcı bir şekilde ortaya koyulmuş olmasına rağmen, hazırlanışı ve özniteliklerinden dolayı başarısız olabilmektedir (Shi ve ark., 2021). Bu nedenlerden ötürü Türkiye'de sosyal girişimciliği sağlayan KF dinamiklerinin daha iyi anlaşılması için platformların verimliliğinin ortaya koyulup özniteliklerle birlikte değerlendirilmesi gerekmektedir.

Bu kapsamda ortaya koyduğumuz araştırmada, Türkiye'deki sosyal girişimcilik dinamikleri incelenmiş ve faaliyet gösteren KF platformlarındaki projeler veri kazıma teknikleriyle toplanıp platformlara göre içerik analizi gerçekleştirilmiştir. 
Çalışmanın özniteliklere, kategorilere, başarı durumlarına, konuma ve fonlamaya göre elde edilen sonuçları bulgular kısmında, KF gelişimi için öneriler ise tartışma ve sonuç bölümlerinde değerlendirilmiştir.

\section{KITTLE FONLAMASI BILLEȘENLERİ VE TÜRLERİ}

KF platformları temel olarak proje sahibi, kitle fonlaması platformu ve proje destekçileri olmak üzere 3 ana bileşenden oluşmaktadır (Şekil 1).

Proje Sahibi: Fikirlerini hayata geçirebilmek, ürününü test etmek veya bir sorunu çözebilmek amacıyla farkındalık sağlamak için KF platformları üzerinden finansal destek talebinde bulunan kullanıcı grubudur. Finansal desteğin sağlanabilmesi için proje sahiplerinin projenin hazır olduğuna dair destekçilere işaret verebilmesi gerekmektedir (İzmirli Ata, 2018). Çünkü destekçiler projeyle ilgili; ödül sayısı, hedeflenen fon tutarı, içerik metni, kampanya gün sayısı, sosyal medya etkinliği gibi başarı faktörlerine odaklanmaktadır. Bu sebeple projenin hazır olduğuna dair sinyalin sadece proje oluşturucusu tarafından algılanması hedeflenen fon miktarı / destekçi oranını yükseltmektedir (Kromidha ve Robson, 2016). Diğer bir deyişle projenin destekçi sayısını azaltmaktadır. Dolayısıyla KF ekosisteminde, döngüyü başlatan konumunda bulunan proje sahibinin proje hazırlama süreçlerinde dikkat etmesi gerekmektedir.

Kitle Fonlaması Platformu: KF platformları, web üzerinden proje sahibi ile proje destekçileri arasında aracılık görevi üstlenmekte ve coğrafi engelleri ortadan kaldırmaktadır (Valančienè ve Jegelevičiūtè, 2013). Bu doğrultuda platformda bulunan proje sahipleri, kampanyalarını yayınladıktan sonra yine aynı platform üzerinde bulunan proje destekçilerinin sağladığı finansal destek KF platformu üzerinde toplanır. Toplanan fon üzerinden \%5-10 arasında komisyon ücreti kesildikten sonra ise geriye kalan fon, proje sahibine aktarılmaktadır (Atsan ve Oruç Erdoğan, 2015).

Proje Destekçileri-Yatırımcılar: KF platformları üzerinde karşılıklı ya da karşı1ıksız finansal destek sağlayan, genellikle yatırım geçmişi olmayan ve inovasyona önem veren kullanıcı grubudur. Bu grup, küçük miktarda katkı sağlayan büyük bir kitleden oluşmakta ve kapsamlı bir etki sağlayabilmektedir. Fakat melek yatırımcılar ve yatırım konusunda uzman olan kişilerin de son zamanlarda özellikle paya dayalı KF platformları üzerinden yatırım yaptıkları gözlemlenmektedir. Bu sebeple proje destekçileri-yatırımcılar grubundaki kullanıcı profili zamanla değişebilme potansiyeline sahiptir.

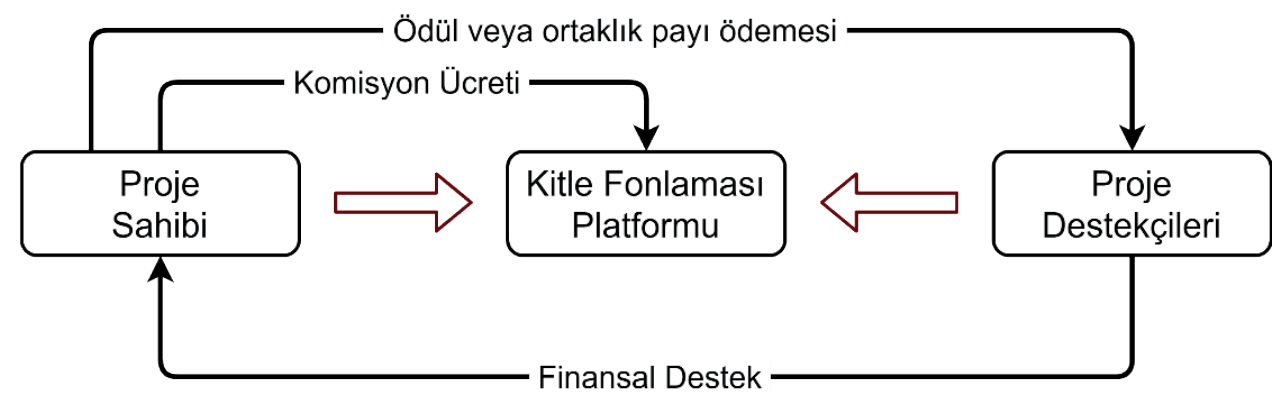

Şekil 1. Kitle fonlamasındaki taraflar (Açıkgöz ve ark., 2020; Valančienė ve Jegelevičiūtè, 2013)

Diğer taraftan, fon sağlayıcılardan elde edilecek katkılardan dolayı elde edilecek sonuçlara dayanarak KF platformları; ödül tabanlı, bağış tabanlı, hisse tabanlı ve borç tabanlı olmak üzere 4 başlık altında incelenmektedir (Alazazi ve ark., 2020; Belleflamme ve Lambert, 2016). 4 ayrı türün tamamı, sermaye elde edebilmek için kitle kaynaklı mekanizmaya güvenmektedir (Frydrych ve ark., 2014). Ayrıca 4 KF türü içerisinde ödül ve bağış tabanlı platformlar yardım, paya dayalı ve borç tabanlı platformlar ise yatırım başlıkları altında değerlendirilmektedir (Tablo 1).

\section{1. Ödül Tabanlı Kitle Fonlaması}

Ödül tabanlı kitle fonlaması platformlarında proje oluşturucusu, desteği sağlayan kişilere maddi veya maddi olmayacak şekilde çeşitli ödüller sağlamaktadır (Zengin ve ark., 2017). Bu ödüller projenin yapısına, ortaya koyuluş şekline ve verilen destek miktarına göre değiş̧iklik gösterebilmektedir. Örneğin, bir ürün tasarlayan proje oluşturucusu yüksek miktarda destek aldığı kullanıcılara ürünün prototipini gönderebilir ya da projede ismine yer verebilir. Benzer şekilde verilen destek miktarına göre proje oluşturucusu destekçilere; teşekkür kartlarının gönderilmesi, sosyal medya üzerinden destekçinin paylaşılması, 
telefonla arayarak teşekkür etme, projeyle ilgili bir toplantıya davet etme gibi maddi olmayacak şekilde küçük jestlerle bir ödül sağlayabilir.

\subsection{Bağıș Tabanlı Kitle Fonlaması}

Bağış tabanlı kitle fonlaması, destekçilerin herhangi bir karşılık beklemediği fonlama türüdür. Diğer bir deyişle, proje destekçileri verdikleri finansal destek karşılığında herhangi bir maddi kazanım elde etmemektedir (Çonkar ve Canbaz, 2018). Bu KF türü genellikle toplumu ilgilendiren konularda, sosyal sorumluluk ve yardımlaşma projelerinde kullanılmaktadır.

\subsection{Paya Dayalı (Hisse Tabanlı) Kitle Fonlaması}

Paya dayalı kitle fonlaması, bir iş fikri ya da girişim tarafından ihtiyaç duyulan fonun kitlelerden temin edilmesinin yanı sıra destekçilerin projeye ortak olduğu KF türüdür (Ahlers ve ark., 2015). Yurtdışında uzun zamandır uygulanmasına rağmen Türkiye'de 2019 yılında "Paya Dayalı Kitlesel Fonlama Tebliği” ile hukuksal zemine kavuşmuştur. Sermaye Piyasası Kurulu (SPK)'dan alınan lisans sonrası 2021'in Nisan ayında fonbulucu.com tarafından Türkiye'de ilk kez hayata geçirilmiştir. Mayıs 2021'de platformdaki ilk proje olan PromoSEED isimli akıllı bakteri teknolojisi projesi kısa bir süre içerisinde hedeflediği fonun çok üzerinde bir fon toplamayı başarmıştır. Bu noktada, nitelikli yatırımcıların da paya dayalı KF üzerinden fonlama gerçekleştirdiği gözlemlenmektedir (Bloomberg, 2021).

\subsection{Borç Tabanlı Kitle Fonlaması (P2P)}

Borç tabanlı kitle fonlaması, kullanıcıların kitlelerden fon toplayıp projenin başarılı olması halinde aldığı borcun faiziyle ödendiği fonlama türüdür (Akyıldız, 2021). Diğer bir deyişle, fona ihtiyaç duyan kişiler ile fon fazlası olan ve yatırım geliri elde etmek isteyen kişileri bir araya getiren yapıdır. Günümüzde uygulanan mevzuatlarla birlikte, borç tabanlı platformlar paya daya dayalı platformlarla beraber yatırım ve yatırımcı barındırdığı için finansal piyasalara dair düzenleme kapsamında değerlendirilmektedir (Gago ve Zeytinler, 2020). Fakat borca dayalı KF platformları için SPK henüz bir düzenleme yapmamıştır. Bu sebeple borç tabanlı platformlar için ikincil bir düzenleme beklenmektedir (Tablo 1).

Tablo 1

Kitle fonlaması türlerinin yasal mevzuatlart

\begin{tabular}{|c|c|c|c|}
\hline Kullanım Amacı & KF Türleri & Temel Düzenleme & Düzenleyici Otorite \\
\hline \multirow{2}{*}{ Yardım Amaçlı KF } & Ödül Tabanlı & Yardım Toplama Kanunu + Borçlar Kanunu & - \\
\hline & Bağış Tabanlı & Yardım Toplama Kanunu + Borçlar Kanunu & - \\
\hline \multirow{2}{*}{ Yatırım Amaçlı KF } & Paya Dayalı & SPK md.35/A Paya Dayalı Kitle Fonlaması Tebliği (III-35/A.1) & SPK \\
\hline & Borç Tabanlı & SPK md.35/A & SPK \\
\hline
\end{tabular}

\section{LITERATÜR ARAȘTIRMASI}

Kitle fonlamasıyla ilgili literatüre bakıldığında dünya çapında birçok çalışmaya rastlanılmaktadır. Ele alınan konu, son 10 yıl içerisinde popülerliğini arttırdığı ve girişimciliği sosyal boyuta taşıdığı için girişimcilerin yanı sıra sosyal ve fen bilimlerindeki araştırmacıların da oldukça ilgisini çekmektedir. Bu doğrultuda KF ile ilgili yapılan çalışmalar 2 farklı başlık altında incelenmiştir.

\section{1. İçerik Analizleri ve İncelemeler}

Çubukçu'nun 2017'de gerçekleştirdiği araştırmada Türkiye'de faaliyet gösteren 5 KF platformu içerik analizi yöntemiyle incelenmiştir. Çalışmanın sonuçlarına göre 2017 itibariyle toplam 485 projenin 144 tanesi başarılı olmuş ve bir projenin gerçekleştirilmesini isteyen destekçiler, projeye ortalama 215 TL destek vermiştir (Çubukçu, 2017). Sakarya ve Bezirgan tarafından 2018'de gerçekleştirilen bir başka çalışmada ise kitle fonlaması platformları Türkiye ve yurt dışı başlıkları altında karşılaştırılmıştır. Çalışmanın sonuçlarına göre, 3 farklı platformun incelenmesiyle 2018 itibariyle Türkiye'de 103 projenin başarılı tamamlandığı vurgulanmıştır. Ayrıca verilen desteklerin baz alınmasıyla, başarılı bir proje için verilen ortalama fon tutarının Türkiye'de 144 dolar iken, yurt dış1 örneğinde bu tutarın 7967 dolar olduğu belirtilmiştir (Sakarya ve Bezirgan, 2018). Atsan ve Erdoğan tarafından yürütülen bir başka çalışmada ise 2015 yılındaki dinamiklere göre mevcut literatür incelenerek bir bilgi kaynağı oluşturulmuştur. Çalışmada dikkat çeken noktalardan bir tanesi Türkiye'deki sosyal girişimciliğin 
incelendiği bölüm olarak göze çarpmaktadır. Bu bölümde ortaya koyulan $4 \mathrm{KF}$ platformundaki rakamlara göre 2015 yılında 2529 yatırımcıdan toplamda 406.523 TL fon toplanıldığı görülmektedir (Atsan ve Oruç Erdoğan, 2015). 2014 yılında Mollick tarafından gerçekleştirilen bir başka araştırmada yaklaşık 50.000 adet projeden oluşan bir veri seti analiz edilmiştir. Elde edilen bulgulara göre projelerin 237 milyon dolardan fazla fon aldığı görülmektedir. Ayrıca çalışma içerisinde proje oluşturucuların fon oluşturabilme başarısının projelerinin kalitesine, destekçilerden talep edilen miktara ve sosyal medyadaki etkinliğe bağlı olduğu da belirtilmiştir (Mollick, 2014). Borrero ve diğerlerinin yaptığı çalışmada, coğrafi konum değişkeni, insan sermayesi, cinsiyet ve deneyimin KF platformlarındaki başarı için büyük rolü olduğu vurgulanmaktadır. Çalışmada ayrıca İspanya'daki destekçilerin, proje sahibinin geçmiş deneyimlerine önem verdikleri belirtilmiştir (Borrero-Domínguez ve ark., 2020).

\subsection{Başarı Sinyalini Yakalama ve Faktör Analizleri}

$\mathrm{Bu}$ bölümde KF platformlarındaki proje özniteliklerinin kullanılmasıyla başarı sinyalini yakalama ve başarı faktörlerini analiz eden çalışmalar incelenmiştir.

Li ve diğerlerinin 2016 yılında gerçekleştirdiği çalışmada KF projelerinde başarı tahmini için sınıflandırma temelli yaklaşıma değinilmiş ve veri setindeki başarılı-başarısız proje sayısı dengesinin iyi kurulması gerektiği açıklanmıştır. Çalışmada önerilen diğer unsurlardan bir tanesi de proje yaratıcılarının, proje başlamadan önce hedef miktara ulaşma açısından diğer projelere göre nerede durdukları hakkında fikir sahibi olmalarının sağlanmasıdır. Bu öneri, karar destek süreçlerini yansıtmaktadır (Li ve ark., 2016). Gürler ve Çağlar'ın 2021 yılında yapmış oldukları bir başka araştırmada 8896 proje ve 19 öznitelik kullanılarak WEKA üzerinde projelerin başarı sınıflandırması yapılmıştır. Elde edilen deneysel sonuçlar karar ağaçlarıyla \%74.55 doğruluk oranı ortaya koymaktadır (Gürler ve Çağlar, 2021). Qianzhou ve diğerlerinin 2021'de gerçekleştirdiği araştırmada proje başarısının tahmini için destekçilerin ikna kabiliyetleri değerlendirilmiştir. Kickstarter'da yayınlanmış olan 183.886 proje verisinin kullanıldı̆̆ çalışmanın sonuçları bir destekçinin daha önceki tercihlerine benzeyen bir proje tarafından ikna edilme olasıllı̆̆ının daha yüksek olduğunu göstermektedir (Du ve ark., 2021). Xiao ve ekibi tarafından yapılan bir başka araştırmada, destekçilerin bir projeyi finanse etme olasılığını tahmin etmek için derin öğrenmeye dayalı tavsiye yaklaşımı önerilmiştir. Çalışmanın sonuçlarına göre ortaya koyulan yaklaşımın öznitelik etkileşimlerini öğrenebileceği, tanımlayabileceği ve KF projesinin performansının iyileştirilebileceği gösterilmiştir (Xiao ve ark., 2021). Jhaveri ve diğerlerinin 2019'da ortaya koyduğu diğer bir çalışmada, proje başarısını en çok etkileyen faktörlerin kampanya gün sayısı, hedef miktarı, projenin kategorisi, konum ve medya içerikleri olduğu belirtilmiştir. Ayrıca çalışma içerisinde Random Forest, CatBoost, XGBoost ve AdaBoost algoritmalarıyla başarı tahmini yapılmış ve AdaBoost \%84 ile en iyi sonucu vermiştir (Jhaveri ve ark., 2019). Alazazi ve diğerlerinin yaptığı araştırmada, KF platformlarına eklenen projelerdeki hedef miktarı, kampanya yorum sayısı, sosyal medyadaki etki ve proje görselleri özniteliklerinin başarıyı etkilediği görülmektedir. Çalışmada ayrıca makine öğrenmesi algoritmalarıyla başarı tahmini yapılmış ve en iyi sonucu Destek Vektör Makineleri (SVM) algoritması vermiştir (Alazazi ve ark., 2020). Koch ve Siering'in 2015 yılında yaptı̆̆ı araştırmada ise, proje açıklamasına dahil edilen metin, resim ve video şeklindeki kapsamlı bilgilerin finansman başarısını pozitif anlamda etkilediği belirtilmiştir. Ayrıca çalışma, gelecek araştırmalarda proje açıklaması gibi özniteliklerde daha derine inilerek kelime sayısının veri setine dahil edilmesini önermektedir (Koch ve Siering, 2015).

Literatür dinamikleri özetlendiğinde, yapılan çalışmalar genellikle büyük çaptaki KF platformlarının (Kickstarter ve Indiegogo) analizine yöneliktir. Fakat Türkiye özelinde de ele alındığında yapılan çalışmaların sayısının artış gösterdiği gözlemlenmektedir. Çalışmaların birçoğunda dikkat çeken ortak nokta KF platformu sayısının dünya çapında oldukça fazla artmasından dolayı süregelen kalite eksikliği sinyalidir. Öyle ki, Türkiye'de ve yurtdışında projelerin başarı oranları geçmişe göre düşüş eğilimindedir. Bu düşüş eğiliminin farkında olan araştırmacılar projelerin başarı tahmini yapılabilmesi için bölüm 3.2'de de belirtildiği gibi birçok çalışma gerçekleştirmiştir. Fakat bu çalışmalar son kullanıcılara uygulama şeklinde sunulmadığı için projelerdeki genel kalite eksikliği sorunu devam etmektedir. Bu nedenle fon sağlayıcılara projeye dair kalite sinyali sağlanabilmesi için Türkiye'de faaliyet gösteren KF platformları detaylı olarak incelenmiştir. 


\section{YÖNTEM}

Türkiye'deki KF ekosisteminde Fongogo, Crowdfon, Fonbulucu, Arıkovanı, Buluşum ve Ideanest gibi platformlar faaliyet göstermektedir (Arıkovan1, 2021; Buluşum, 2021; Crowdfon, 2021; Fonbulucu, 2021; Fongogo, 2021; Ideanest, 2021). Araştırmadaki hedef, bu platformlarda yayınlanmış olan projeler hakkında güncel açıklayıcı istatistiklere ulaşarak; karşılaştırma ve değerlendirme yapmaktadır. Bu doğrultuda, web sitesi olarak son kullanıcıyla buluşarak proje oluşturucu ve proje destekçilerine ulaşan bu platformların tüm meta alanları veri kazıma teknikleriyle toplanmıştır. Sonrasında ise içerik analizi yöntemiyle oluşturulan veri seti incelenmiştir. Analiz sonuçlarıyla elde edilen karşılaştırma ve değerlendirmeler Türkiye'deki KF ekosisteminin mevcut durumunu özetlemeyi hedeflemektedir.

\subsection{Veri Seti}

Çalışma kapsamında, Türkiye'de faaliyet gösteren KF platformları bünyesindeki halka açık ve üyelik gerektirmeden ulaşılabilen meta alanları, veri kazıma teknikleriyle toplanmıştır. Her KF platformunun meta alanları sürece dahil edilirken farklı yazılım kütüphanelerine ve araçlara ihtiyaç duyulmuştur. Bu sebeple yapılan araştırmadaki veri kazıma işleminde platformlara göre değişik yöntemler kullanılmıştır (Tablo 2).

Tablo 2

Veri kazımada kullanılan yazılım kütüphaneleri ve araçlar

\begin{tabular}{ccc}
\hline Nesne Tabanlı Programlama Dili (OOP) & Yazılım Kütüphaneleri & Araçlar \\
\hline \multirow{2}{*}{ Phyton } & BeautifulSoup & Webrobots.io \\
& Scrapy & MS Excel \\
& Requests & Octoparse \\
& & WebHarvy \\
\hline
\end{tabular}

Bu doğrultuda, BeautifulSoup ve Scrapy kütüphaneleri Phyton ile derlenen, HTML veya XML dosyalarını işleyebilmek için oluşturulmuş yazılım kütüphaneleridir ve çalışma içerisinde veri kazıma araçlarının işlevsiz kaldığı durumlarda kullanılmışlardır.

Tablo 3

Veri setinin özellikleri

\begin{tabular}{|c|c|}
\hline Başarı Faktörleri & Açıklama \\
\hline Destekçi Sayısı & Kampanyada sunulan ödüllerden satın alarak projeye destek olan kişilerin sayısı \\
\hline Hedef Miktarı & Projenin gerçekleştirilebilmesi için proje sahibinin destekçilerden istediği fon \\
\hline Görsel Sayısı & Kampanya galerisine eklenmiş olup proje tanıtımı için \\
\hline $\begin{array}{l}\text { Güncelleme ve S1kça Sorulan Sorular (SSS) } \\
\text { Sayıs }\end{array}$ & Projenin kampanya gün sayısı bitene kadar yapılan güncelleme ve SSS sayısı \\
\hline Yorum Sayıs1 & Proje ile ilgili destekçilerden gelen yorumların sayısı \\
\hline Etiket Sayıs1 & Proje sahibi tarafından oluşturulan açıklayıcı etiketlerin sayısı \\
\hline Açıklama Metni ve İçerik Kelime Sayısı & Projenin destekçilere tanıtıldığı metnin içerisindeki kelime sayısı \\
\hline Toplanan Tutar ve Destek Oranı & Sunulan hedef miktarı ile kampanya gün sayısı içinde toplanan para miktarı ve destek oranı \\
\hline Tanıtım Videosu Toplam Saniye & Proje için hazırlanan tanıtım videosunun saniye cinsinden uzunluğu \\
\hline Ödül Sayısı & Proje sahibinin destekçiler için hazırlamış olduğu ödüllerin sayısı \\
\hline Sosyal Medya Takipçi Sayısı & Projeye ait Facebook, Instagram, Twitter veya Linkedin hesaplarındaki toplam takipçi sayısı \\
\hline Başladığı Tarih & Projenin destekçilere sunulduğu tarih \\
\hline Kampanya Gün Sayısı & Projenin KF platformunda destek beklediği aktif gün sayısı \\
\hline Ekip Kişi Sayısı & Proje ekibinde bulunan kişi sayısı \\
\hline Desteklediği Proje Sayısı & Proje sahibinin KF platformunda desteklediği projelerin sayısı \\
\hline Abone Olduğu Proje Sayısı & Proje sahibinin KF platformunda abone olduğu proje sayısı \\
\hline Platformdaki Proje Sayısı & Proje sahibinin KF platformundaki toplam proje sayısı \\
\hline Bulunduğu Proje Takımı Sayısı & Proje sahibinin KF platformu içerisindeki diğer projelerde ekipte yer alma sayısı \\
\hline Cinsiyeti & Proje sahibinin cinsiyeti \\
\hline Projenin Konumu & Projenin gerçekleştiği yer veya proje sahibinin bulunduğu konum \\
\hline Proje Kategorisi & KF platformu içinde en az 1 proje bulunduran proje kategorileri \\
\hline Fonlama Şekli & "Ya hep ya hiç" veya "hepsi kalsın" modeline göre oluşturulan projeler \\
\hline Web Sitesi & Projeye ait bir web sitesinin olup olmadiğ 1 \\
\hline Sosyal Medya Hesap & Projeye ait Facebook, Instagram, Twitter veya Linkedin hesaplarının olup olmadığı \\
\hline Tanıtım Videosu & Proje tanıtımı için hazırlanmış bir video olup olmadığı \\
\hline Başarı Durumu & Kampanya gün sayısı içerisinde hedef miktarına ulaşan proje başarılı, diğerleri başarısız sayılır. \\
\hline
\end{tabular}


Veri kazıma araçları olan Webrobots, Octoparse ve WebHarvy ise platformlara göre değişkenlik gösterecek şekilde verinin tutulduğu MS Excel tablosunun oluşturulmasında kullanılmıştır. Veri kazıma kütüphane ve araçlarının kullanılamadığı durumlarda ise manuel olarak veri toplama işlemi gerçekleştirilmiştir. Bu kapsamda, Mart 2021 ile Temmuz 2021 tarihleri arasındaki 5 aylık süreçte toplamda 1635 veriden oluşan Türkiye KF veri seti oluşturulmuştur. Veri kazıma ile elde edilen sonuçlara göre ödül ve bağış tabanlı platformlardaki projeler 19 nümerik, 8 kategorik başarı faktörü altında toplanmaktadır. Bu doğrultuda oluşturulan veri seti özellikleri tablosu başarı faktörleri ve açılamaları ile eşleştirilmişsir (Tablo 3).

\section{BULGULAR}

Türkiye'de faaliyet gösteren KF platformlarındaki projelerin çeşitli kriterlere göre içerik analizleri yapılarak açıklayıcı istatistiklerle birlikte bu bölümde yer verilmiştir. Mart 2021 ve Temmuz 2021 tarihlerinde yapılan veri toplama işlemlerinden elde edilen verilerle oluşan analizler aşağıda bölümlerde detaylıca gösterilmiş̧ir.

\subsection{Kategoriye Göre Dağılımlar}

Proje sayısı arttıkça Türkiye'deki KF platformları, farklılık göstermekle birlikte 17 ayrı kategoride proje eklemeye olanak sağlamaktadır. Kategorilerle ilgili detaylar, Tablo 4 ile birlikte aşağıda yer verilmiştir. Tablo 4'teki "Kategori Yüzdelik Dilim (KYD)", seçili kategorinin tüm kategoriler içindeki yüzdesini ifade etmektedir. Diğer sütunlarda platformlara göre proje sayıları verilmiş olup seçili kategorideki toplam proje sayısı (TPS), başarılı proje sayısı (BPS) ve kategorinin başarı yüzdesi yer almaktadır (Tablo 4). Tabloya göre;

- Teknoloji kategorisi, toplamda 347 projeye sahip olup tüm kategoriler arasında \%21,21'lik paya sahiptir ve Buluşum hariç tüm platformlarda bulunmaktadır. Başarı yüzdesi $\% 15,85$ olan teknoloji, tüm kategoriler arasında proje sayısı bakımından 2. siradadir.

- Çevre kategorisi, 98 projeyle \%5,9'luk bir alanı oluşturmaktadır ve yalnızca Fongogo, Crowdfon ve Fonbulucu üzerinde kullanıcılara sunulmaktadır. 22 başarılı projenin bulunduğu kategoride başarı oranı \%22,45 olarak bulunmuştur.

- Film-Video-Fotoğraf, en fazla projenin yer aldığı kategori olup toplamda 390 projenin listelendiği KF kategorisidir. Fongogo, Crowdfon ve Buluşum platformlarında aktif olan kategori, $\% 23,85^{\prime}$ lik bir paya sahiptir ve 134 başarılı proje sayısıla başarı yüzdesi $\% 34,36$ 'dır.

- Eğitim kategorisi, 187 projenin yer aldığı ve 60 projenin başarıyla fonlandığı bir kategori olup \%32 başarı yüzdesine sahiptir. Kategorideki projeler, tüm projeler içindeki \%11,43 yüzdelik dilimi içindedir.

- Turizm, 6 projenin yer aldığı ve 2 projenin başarılı olduğu bir kategori olarak KF platformlarında yer almaktadır. \%33 başarı yüzdesine sahip kategori, tüm projelerin \%0,3’ünü oluşturmaktadır.

- Fongogo, Crowdfon, Fonbulucu platformlarında bulunan Gıda-Yeme-İçme kategorisi 3'ü başarılı olmak üzere 27 projeye sahiptir ve başarı oranı \%11 olarak bulunmuştur. Gıda-Yeme-İçme tüm projelerin \%1,65'ini oluş̧urmaktadır.

- 2'si başarı11 olmak üzere toplam 11 projeden oluşan Moda kategorisinin başarı yüzdesi \%18 olarak bulunmuştur. Fongogo ve Crowdfon'da bulunan kategori, tüm projelerin \%0,67’sini oluşturmaktadır.

- Crowdfon ve Fonbulucu'da mevcut olan Tasarım kategorisi, 1 tanesi başarılı olmak üzere toplam 33 projeyi kapsamaktadır ve başarı yüzdesi \%3’tür. Tasarım, tüm projelerin \%2'sini oluşturmaktadır.

- 37'si başarılı olmak üzere toplam 194 projenin bulunduğu Kültür-Sanat kategorisi, \%19 başarı yüzdesine sahiptir ve tüm projelerin \%11,86’sını oluşturmaktadır.

- Müzik kategorisi, 11’i başarılı olmak üzere 59 projeden oluşmaktadır. Başarı yüzdesi \%18,64 olan kategorinin tüm projeler içindeki yüzdesi ise $\% 3,6$ 'dır.

- 5’i başarılı olmak üzere toplam 27 projenin oluşturduğu Yayıncılık kategorisi Fongogo ve Crowdfon üzerinde mevcut olup tüm projelerin \%1,65'ini oluşturmaktadır. Ayrıca, \%18,52 başarı yüzdesine sahiptir. 
- Sağlık-Güzellik kategorisi, 17'si başarılı olmak üzere 51 projeden oluşmakta olup tüm projelerin \%3,11'üne denk gelmektedir. Kategorinin başarı yüzdesi \%33’tür.

· 5’i başarılı olmak üzere toplam 20 projeden oluşan Spor kategorisinin başarı yüzdesi \%25 olarak bulunmuştur. Kategori, tüm projelerin \%1,22'sini oluşturmaktadır.

· $\quad$ l'i başarılı olmak üzere toplam 7 projenin oluşturduğu Dans-Performans kategorisi tüm projelerin \%0,42'sine denk gelmektedir. Kategorinin başarı yüzdesi \%14,29’dur.

· Başarılı bir şekilde fonlanan proje bulunmayan Hayvanlar kategorisi 13 projeye sahip olup tüm projelerin \%0,79’unu oluşturmaktadır.

- 5 başarılı projenin yer aldığı ve toplam 10 projeden oluşan Sosyal Sorumluluk kategorisi, tüm projelerin \%0,61’ini oluşturmaktadır. Kategorinin başarı yüzdesi \%50’dir.

- Son olarak Diğer kategorisinde 19’u başarılı olmak üzere toplam 155 proje bulunmaktadır. Tüm projelerin \%9,48'ine denk gelen kategorinin başarı oranı ise \%12,26'dır.

Bulgular incelendiğinde örneklem sayısı yeterli olan Film-Video-Fotoğraf ve Eğitim kategorilerindeki projelerin fonlama yüzdelerinin daha yüksek olduğu gözlemlenmektedir (Tablo 4). Fakat bu noktada Teknoloji kategorisine ayrı bir parantez açmak gerekmektedir. Çünkü en fazla meta alanına sahip kategorilerden biri olan teknoloji, yalnızca Arıkovanı’nda \%67,2 ile fonlanmaktadır. Bu durum aslında, fonlama başarısı için yalnızca kategoriye bakılmamasını gösteren en belirgin etkenlerden birisidir. Öyle ki, KF başarısına kategori haricinde birçok öznitelik etki etmektedir.

Tablo 4

Tüm projelerin kategoriye göre dă̆llımları

\begin{tabular}{|c|c|c|c|c|c|c|c|c|c|c|c|}
\hline Kategori & Fongogo & Crowdfon & Fonbulucu & Arıkovanı & Buluşum & $\begin{array}{c}\text { Fonbulucu } \\
\text { (Hisse) }\end{array}$ & Ideanest & TPS & BPS & $\begin{array}{c}\text { Başarı } \\
\text { Yüzdesi }\end{array}$ & KYD \\
\hline Teknoloji & 116 & 67 & 97 & 58 & - & 4 & 5 & 347 & 55 & $\% 15,85$ & $\% 21,22$ \\
\hline Çevre & 43 & 24 & 31 & - & - & - & - & 98 & 22 & $\% 22,45$ & $\% 5,9$ \\
\hline $\begin{array}{l}\text { Film-Video- } \\
\text { Fotoğraf }\end{array}$ & 348 & 41 & - & - & 1 & - & - & 390 & 134 & $\% 34,36$ & $\% 23,85$ \\
\hline Eğitim & 156 & - & 26 & - & 3 & 1 & 1 & 187 & 60 & $\% 32$ & $\% 11,43$ \\
\hline Turizm & 6 & - & - & - & - & - & - & 6 & 2 & $\% 33,3$ & $\% 0,36$ \\
\hline Gıda-Yeme-İçme & 24 & 1 & 1 & - & - & 1 & - & 27 & 3 & $\% 11,1$ & $\% 1,65$ \\
\hline Moda & 10 & 1 & - & - & - & - & - & 11 & 2 & $\% 18,18$ & $\% 0,67$ \\
\hline Tasarım & - & 17 & 16 & - & - & - & - & 33 & 1 & $\% 3$ & $\% 2$ \\
\hline Kültür-Sanat & 157 & 14 & 19 & - & 4 & - & - & 194 & 37 & $\% 19$ & $\% 11,86$ \\
\hline Müzik & 42 & 14 & 3 & - & - & - & - & 59 & 11 & $\% 18,64$ & $\% 3,6$ \\
\hline Yayıncılık & 9 & 18 & - & - & - & - & - & 27 & 5 & $\% 18,52$ & $\% 1,65$ \\
\hline Sağlık-Güzellik & 39 & - & 7 & - & - & 1 & 4 & 51 & 17 & $\% 33$ & $\% 3,11$ \\
\hline Spor & 18 & - & 2 & - & - & - & - & 20 & 5 & $\% 25$ & $\% 1,22$ \\
\hline Dans-Performans & 7 & - & - & - & - & - & - & 7 & 1 & $\% 14,29$ & $\% 0,42$ \\
\hline Hayvanlar & - & - & 13 & - & - & - & - & 13 & 0 & 0 & $\% 0,79$ \\
\hline $\begin{array}{l}\text { Sosyal } \\
\text { Sorumluluk }\end{array}$ & - & - & 5 & - & 5 & - & - & 10 & 5 & $\% 50$ & $\% 0,61$ \\
\hline Diğer & 100 & 40 & 15 & - & - & - & - & 155 & 19 & $\% 12,26$ & $\% 9,48$ \\
\hline
\end{tabular}

\subsection{Başarı Durumlarına Göre Dağılımlar}

KF platformlarındaki projeler, oluşturulan veri seti içerisinde başarı durumlarına göre incelenmiştir. Elde edilen bulgulara göre, Fongogo'da 284'ü başarılı olmak üzere toplam 1075 proje mevcut olup başarı yüzdesi \%26,41 olarak bulunmuştur. 
Tablo 5

Platformlara göre kitle fonlaması projelerinin başarı durumları

\begin{tabular}{|c|c|c|c|c|c|c|}
\hline KF Türü & Platform Adı & Aktiflik Durumu & $\begin{array}{c}\text { Başarılı Proje } \\
\text { Sayısı }\end{array}$ & $\begin{array}{c}\text { Başarısız Proje } \\
\text { Sayısı }\end{array}$ & $\begin{array}{c}\text { Toplam Proje } \\
\text { Sayıs }\end{array}$ & Başarı Yüzdesi \\
\hline \multirow{5}{*}{ Ödül Tabanlı } & Fongogo & Aktif & 284 & 791 & 1075 & $\% 26,41$ \\
\hline & Crowdfon & Aktif & 16 & 221 & 237 & $\% 6,75$ \\
\hline & Fonbulucu & Aktif & 15 & 220 & 235 & $\% 6,38$ \\
\hline & Arıkovanı & Aktif & 39 & 19 & 58 & $\% 67,2$ \\
\hline & Buluşum & Pasif & 13 & 0 & 13 & $\% 100$ \\
\hline $\begin{array}{l}\text { Hisse } \\
\text { Tabanlı }\end{array}$ & Fonbulucu (Hisse) & Aktif & 3 & 4 & 7 & $\% 42,8$ \\
\hline $\begin{array}{l}\text { Bağış } \\
\text { Tabanlı }\end{array}$ & Ideanest & Pasif & 9 & 1 & 10 & $\% 90$ \\
\hline Genel Toplam & & & 379 & 1256 & 1635 & $\% 23,18$ \\
\hline
\end{tabular}

Crowdfon'da 16'sı başarılı olmak üzere toplam 237 proje bulunmaktadır. Başarı yüzdesi ise \%6,75'tir. Fonbulucu'nun ödül tabanlı olan platformunda 15'i başarılı olmak üzere 235 proje yer almaktadır ve başarı yüzdesi \%6,38'dir. Paya dayalı olan bölümünde ise 3’ü başarılı olmak üzere 7 proje bulunmakta olup başarı yüzdesi \%42,8 olarak bulunmuştur. Ayrıca paya dayalı oluşturulan yapıda henüz başarılı kabul edilmeyen projelerin fonlama süreçleri devam etmektedir. Yalnızca teknoloji kategorisinde faaliyet gösteren Arıkovanı platformunda 39'u başarılı olmak üzere toplam 58 KF projesi bulunmaktadır. Başarı yüzdesi ise \%67,2 olarak bulunmuştur. Pasif bir görünümde olan Buluşum platformunda yayınlanan tüm projeler hedef miktarını aşarak desteklenmiştir. Son olarak revizyon sebebiyle pasif durumda olan bağış tabanlı Ideanest platformunda 9'u başarılı olmak üzere toplamda 10 proje bulunmakta olup bu projelerin yalnızca 1 tanesi desteklenmemiştir. Tüm platformlardaki projeler ele alındığında 379’u başarılı olmak üzere toplamda 1635 proje bulunmaktadır. Bu doğrultuda, Türkiye'deki KF platformlarındaki proje ve kampanyaların başarı oranı \%23,18 olarak bulunmuştur (Tablo 5).

\subsection{Fonlamaya Göre Dağılımlar}

KF projelerinin fonlama dağılımları proje oluşturucusunun belirlediği hedef miktar, destekçilerden gelen fon miktarı ve toplam destekçi sayısına göre belirlenmiştir. Bu doğrultuda oluşturulan tabloda; "başarılı projelere aktarılan fon”, \%100 ve daha fazla oranda desteklenen projeleri ifade etmektedir. Yani, \%100 altında desteklenen projelerdeki fonlar proje sahibine aktarılmadığ 1 için bu kısma dahil edilmemiş olup “toplanan fon miktarı” bölümünde değerlendirilmiştir. "Proje başına düşen ortalama fon" bölümü, toplanan fon miktarının ilgili platformdaki toplam sayısına bölünmesiyle bulunmuştur. Benzer şekilde "başarılı proje başına düşen ortalama fon” bölümü de başarılı projelere aktarılan fonun ilgili platformdaki toplam başarılı proje sayısına bölünmesiyle elde edilmiştir. Son olarak "destekçi başına düşen ortalama fon” ise toplanan fon miktarının fonlayan destekçi sayısına bölünmesiyle bulunmuştur.

Tablo 6

Platformlara göre kitle fonlaması projelerinin fonlama istatistikleri

\begin{tabular}{|c|c|c|c|c|c|c|c|c|}
\hline $\begin{array}{l}\text { KF } \\
\text { Türüi }\end{array}$ & $\begin{array}{c}\text { Platform } \\
\text { Adı }\end{array}$ & $\begin{array}{c}\text { Fonlayan } \\
\text { Destekçi } \\
\text { Sayısı } \\
\end{array}$ & $\begin{array}{l}\text { Hedeflenen } \\
\text { Fon Miktarı }\end{array}$ & $\begin{array}{c}\text { Toplanan Fon } \\
\text { Miktarı }\end{array}$ & $\begin{array}{c}\text { Başarılı } \\
\text { Projelere } \\
\text { Aktarılan Fon }\end{array}$ & $\begin{array}{l}\text { Proje Başına } \\
\text { Düşen Ort. } \\
\text { Fon }\end{array}$ & $\begin{array}{l}\text { Başarılı Proje } \\
\text { Başına Düssen } \\
\text { Ort. Fon }\end{array}$ & $\begin{array}{c}\text { Destekçi } \\
\text { Başına Düşen } \\
\text { Ort. Fon }\end{array}$ \\
\hline \multirow{5}{*}{$\begin{array}{l}\text { Ödül } \\
\text { Tabanlı }\end{array}$} & Fongogo & 26.316 & $24.913 .495 \mathrm{TL}$ & $6.588 .163 \mathrm{TL}$ & $6.574 .748 \mathrm{TL}$ & $6.128 \mathrm{TL}$ & $23.150 \mathrm{TL}$ & $250 \mathrm{TL}$ \\
\hline & Crowdfon & 1.597 & 9.309.269 TL & $160.886 \mathrm{TL}$ & $145.365 \mathrm{TL}$ & $678 \mathrm{TL}$ & $9.085 \mathrm{TL}$ & $100 \mathrm{TL}$ \\
\hline & Fonbulucu & 871 & 10.173.396 TL & $3.693 .542 \mathrm{TL}$ & $3.663 .837 \mathrm{TL}$ & $15.717 \mathrm{TL}$ & $244.255 \mathrm{TL}$ & $4.240 \mathrm{TL}$ \\
\hline & Arrkovanı & 9.668 & $5.474 .100 \mathrm{TL}$ & 7.397.620 TL & $7.246 .252 \mathrm{TL}$ & $127.545 \mathrm{TL}$ & $185.801 \mathrm{TL}$ & $765 \mathrm{TL}$ \\
\hline & Buluşum & 451 & $430.790 \mathrm{TL}$ & $430.790 \mathrm{TL}$ & $430.790 \mathrm{TL}$ & $33.137 \mathrm{TL}$ & $33.137 \mathrm{TL}$ & $955 \mathrm{TL}$ \\
\hline $\begin{array}{l}\text { Hisse } \\
\text { Tabanlı }\end{array}$ & $\begin{array}{l}\text { Fonbulucu } \\
\text { (Invest) }\end{array}$ & 1.634 & $3.850 .000 \mathrm{TL}$ & $3.062 .832 \mathrm{TL}$ & $2.476 .552 \mathrm{TL}$ & $434.547 \mathrm{TL}$ & $825.517 \mathrm{TL}$ & $2356 \mathrm{TL}$ \\
\hline $\begin{array}{l}\text { Bağış } \\
\text { Tabanlı }\end{array}$ & Ideanest & 307 & $385.600 \mathrm{TL}$ & $335.154 \mathrm{TL}$ & $335.154 \mathrm{TL}$ & $38.560 \mathrm{TL}$ & $37.239 \mathrm{TL}$ & $1091 \mathrm{TL}$ \\
\hline \multicolumn{2}{|c|}{ Genel Toplam/Ort. } & 40.844 & $54.536 .650 \mathrm{TL}$ & $\begin{array}{c}21.668 .987 \\
\text { TL }\end{array}$ & $20.872 .698 \mathrm{TL}$ & $13.253 \mathrm{TL}$ & $55.073 \mathrm{TL}$ & 530 TL \\
\hline
\end{tabular}

Tablo üzerinde elde edilen bulgulara göre Türkiye'deki KF ekosisteminin mali olarak büyüklüğü 21.668.987 TL'dir. Bu tutar, tüm platformlardaki toplam 40.844 destekçinin toplam fonlama miktarı ile elde edilmiştir. Ayrıca tüm platformlar ele 
alındığında destekçi başına düşen ortalama fon 530 TL olarak bulunmuştur (Tablo 6). Fonlama dağılımları değerlendirildiğinde, yeni uygulanmaya başlamış olmasına rağmen paya dayalı Fonbulucu platformundaki yüksek fon oranları göze çarpmaktadır. Bunun temel sebebinin tüm dünyada olduğu gibi KF destekçilerinin gelecek vaat eden projelere MKK (Merkezi Kayıt Kuruluşu) aracılığında hisseyle ortak olarak finansal bir kazanç elde etme isteğinden kaynaklandığı söylenebilir. Bu sebeple, önümüzdeki 5 yıl içerisinde paya dayalı platformların sayılarının da artmasıyla bu alanda faaliyet gösteren KF platformlarının fon oranlarında artış olacağı öngörülmektedir. Çünkü ortaklık anlayışına dayanan paya dayalı girişimlerde destekçilere projeyle ilgili; belgeler, ödüller, hukuki durum, finansal tablolar, SWOT analizleri, iş planı, ürün, üretim gibi alanlarda tüm bilgiler verilmekte ve iş fikri iyi bir şekilde pazarlanmaktadır. Bu durum, paya dayalı platformlarda daha fazla fonlama potansiyeli olduğunu göstermektedir. Fakat kullanıcıya kalite sinyalini verebilen, öznitelik bakımından zengin olan ödül ve bağı̧s tabanlı platformlardaki projeler de fonlama için yüksek potansiyele sahip durumdadır.

\subsection{Proje Özniteliklerinin Dağılımları}

Tablo 3’te de belirtildiği üzere KF platformlarından elde edilebilen 27 farklı öznitelik bulunmaktadır. Bu özniteliklerden kategorik olmayan meta alanlarının genel ortalamaları ile öznitelik dağılım tablosu oluşturulmuştur.

Tablo üzerinde elde edilen bulgulara göre, bitmiş olan projelerin kampanya süresi yalnızca Fongogo platformu üzerinde gözüküyor olup diğerlerinde sadece kampanya bitiş tarihleri yer almaktadır. Bu doğrultuda, kampanya sürelerinin genel Türkiye ortalaması 58,2 gündür. Fakat 40 günden az süren kampanyaların hedeflerine ulaşma olasıllı̆̆ 40 günden uzun süren kampanyalara göre \%6 daha yüksektir (Li ve ark., 2016; Lukkarinen ve ark., 2016). Projenin tanıtıldığı alanlardan biri olan görseller ve tanıtım videosu da proje öznitelikleri arasında önemli bir yere sahiptir (Greenberg ve ark., 2013; Orçun ve Boran Sezgin, 2020; Shneor ve Vik, 2020). Tüm platformlar ele alındığında görsel ortalaması 5,92 olarak bulunmuştur. Tanıtım videosunun saniye cinsinden uzunluk ortalaması ise 87,9 saniyedir. Yorum ve güncelleme sayısı destekçilerin projeyle olan etkileşimini ve ilgisini arttırdığı için KF başarısında pozitif bir etkiye sahiptir. Bu kapsamda, KF projelerinin ortalama yorum sayıs1 9,3 güncelleme sayısı ise 1,79 olarak bulunmuştur. Yalnızca ödül tabanlı platformlarda destekçilere fon karşıllğı verilen ödüllerin sayısı, verilecek fon aralığının olması açısından önemlidir ve platformlardaki ortalaması 4,7 olarak belirtilmektedir.

Tablo 7

Diğer özniteliklerin KF platformlarındaki dă̆llım ortalamaları

\begin{tabular}{|c|c|c|c|c|c|c|c|c|c|c|c|}
\hline $\begin{array}{l}\text { KF } \\
\text { Türü̈ }\end{array}$ & $\begin{array}{c}\text { Platform } \\
\text { Adı }\end{array}$ & $\begin{array}{c}\text { Ort. } \\
\text { Kampanya } \\
\text { Süresi }\end{array}$ & $\begin{array}{l}\text { Ort. } \\
\text { Görsel } \\
\text { Sayısı }\end{array}$ & $\begin{array}{l}\text { Tanıtım } \\
\text { Videosu } \\
\text { Uzunluğu } \\
\text { Ort. }\end{array}$ & $\begin{array}{c}\text { Ort. } \\
\text { Yorum } \\
\text { Sayısı }\end{array}$ & $\begin{array}{c}\text { Ortalama } \\
\text { Güncelleme } \\
\text { Sayısı }\end{array}$ & $\begin{array}{l}\text { Ort. } \\
\text { Ödül } \\
\text { Sayısı }\end{array}$ & $\begin{array}{l}\text { Ekipteki } \\
\text { Kişi } \\
\text { Sayısı } \\
\text { Ort. }\end{array}$ & $\begin{array}{l}\text { Sosyal } \\
\text { Medya } \\
\text { Takipçi } \\
\text { Ort. } \\
\end{array}$ & $\begin{array}{c}\text { Proje } \\
\text { Açıklamasındaki } \\
\text { Kelime Sayısının } \\
\text { Ort. }\end{array}$ & $\begin{array}{l}\text { Proje } \\
\text { Sayısı }\end{array}$ \\
\hline \multirow{5}{*}{$\begin{array}{l}\text { Ödül } \\
\text { Tabanlı }\end{array}$} & Fongogo & 48 gün & 6 & $81 \mathrm{sn}$. & 0,1 & 0,59 & 6,56 & 1,9 kişi & 3576 kişi & 400 kelime & 1075 \\
\hline & Crowdfon & 60 gün & 1,22 & $14,7 \mathrm{sn}$ & 0,24 & 0 & 4,14 & 1 kişi & 0 kişi & 103 kelime & 237 \\
\hline & Fonbulucu & 60 gün & 3,65 & $52,65 \mathrm{sn}$. & 0,60 & 0 & 5,63 & 1,4 kişi & 1131 kişi & 328 kelime & 235 \\
\hline & Arıkovanı & 60 gün & 8,8 & 100 sn. & 30,7 & 3,41 & 6,2 & 3,6 kişi & 428 kişi & 634 kelime & 58 \\
\hline & Buluşum & 60 gün & 1 & $0 \mathrm{sn}$. & 0 & 0 & 1 & 1 kişi & 0 kişi & 199 kelime & 13 \\
\hline $\begin{array}{l}\text { Hisse } \\
\text { Tabanlı }\end{array}$ & $\begin{array}{c}\text { Fonbulucu } \\
\text { (Hisse) }\end{array}$ & 60 gün & 21,8 & 214 sn. & 32,1 & 8,57 & - & 5,2 kişi & 1716 kişi & 572 kelime & 7 \\
\hline $\begin{array}{l}\text { Bağış } \\
\text { Tabanlı }\end{array}$ & Ideanest & 60 gün & 0 & $153 \mathrm{sn}$. & 1,4 & 0 & - & 1,3 kişi & 170 kişi & 524 kelime & 10 \\
\hline \multicolumn{2}{|c|}{ Genel Ortalama } & 58,2 gün & 5,92 & 87,9 sn. & 9,3 & 1,79 & 4,7 & 2,2 kişi & 1003 kişi & 394 kelime & 1635 \\
\hline
\end{tabular}

Diğer taraftan, şirketlerin daha fazla insan sermayesine sahip olması rakiplerinden daha iyi performans göstermesini sağlayabilmektedir. Proje ekiplerindeki insan sermayesi de buna dahil olduğu için proje ekibindeki kişi sayısı destekçilere kalite sinyalini veren unsurlardan biridir (Yeh ve Chen, 2020). Bu kapsamda, Türkiye'deki KF projelerinin ekip kişi sayısı ortalaması 2,2 olarak bulunmuştur. Sosyal medya ise KF kampanyalarının daha fazla kişiye ulaşması açısından fayda sağladığından KF başarısını olumlu etkileyen özniteliklerden biridir (Ryoba ve ark., 2020). Çalışma kapsamında KF proje sahiplerinin platform üzerinde belirtmiş olduğu sosyal medya hesaplarının takipçi ortalaması 1003 olarak bulunmuştur. Fakat takipçi sayıları arasında düzensiz bir dağılım mevcuttur. Son olarak, proje metin içerikleri destekçilerin ikna edildiği alan olarak öne çıkmaktadır ve kalite sinyalinin oluşmasında etkisi büyüktür (Zhou ve ark., 2018). Metin içeriğinin yeterince açıklayıcı olması, çok fazla uzun olmaması ve özetleyici bilgiler içermesi beklenir (Yuan ve ark., 2016). Tablo 7'deki bulgulara göre KF proje metin içeriklerinin kelime ortalaması 394'tür. 


\subsection{Proje Konumlarının Dağılımları}

Her ne kadar KF destekçi ve proje sahibi arasındaki coğrafi engelleri ortadan kaldırıyor olsa da, literatürdeki bazı çalışmalarda coğrafi konumun kaynak yaratma açısından önemli bir unsur olduğu belirtilmiştir (Wang ve ark., 2020; Yuan ve ark., 2016). Türkiye'deki projelerin konum verileri incelendiğinde bazı projelerde konum bilgisinin belirsiz olduğu görülmüştür. Bunun nedeni ise ilgili projelerin yüklendiği platformda konumla ilgili bir meta alanının bulunmamasıdır. Belirtilen şekilde konumu belirsiz olan 374 proje bulunmakla birlikte bu projelerin 83’ü başarılı olmuştur. Benzer şekilde, Türkiye geneline hitap eden projeler de "genel” bölge kategorisinde değerlendirilmiştir. Bu doğrultuda genel kategorisinde yer alan 97 projenin 8’i başarılı olmuştur.

Konumu belli olan projelerin 7 farklı coğrafi bölgeye göre dağılımlarına bakıldığında ise, ilk olarak Marmara Bölgesi 638 toplam proje, 193 başarılı proje ile \%30,25'lik bir başarı yüzdesine sahiptir. Ege bölgesi, 19'u başarılı olmak üzere toplamda 136 projenin konum bilgisinde yer almış olup başarı yüzdesi \%13,97 olarak bulunmuştur. Akdeniz bölgesi 26’sı başarılı olmak üzere toplamda 102 projenin konum verisini içermektedir. Başarı yüzdesi \%25,4 olarak göze çarpmaktadır. Karadeniz bölgesi, 9’u başarılı olmak üzere toplam 57 projeye sahiptir ve başarı oranı \%15,78'dir. İç Anadolu Bölgesi, 30’u başarılı olmak üzere 165 projenin konum verisini içermektedir. Başarı oranı ise \%18,18 olarak bulunmuştur. Güneydoğu Anadolu Bölgesi, 11’i başarılı olmak üzere toplamda 46 projeyi kapsamaktadır ve bölgenin başarı oranı \%23,91'dir. Doğu Anadolu Bölgesi'nde ise destekçilere sunulan 19 projenin hiçbiri fonlanmamıştır (Tablo 8).

Konum dağılımları QGIS yazılımıyla oluşturulan haritada değerlendirildiğinde; Marmara, Akdeniz ve Güneydoğu Anadolu Bölgeleri’ndeki başarı yüzdesinin Türkiye ortalamasının üzerinde olduğu gözükmektedir. Ege, Karadeniz ve İç Anadolu Bölgeleri ise başarılı proje yüzdesi bakımından Türkiye ortalamasının altında kalmıştır. Doğu Anadolu Bölgesi’nde ise başarılı proje faaliyeti gerçekleşmemiştir.

İller bazında bakıldığında da destekçi ve yatırımcılara en fazla projenin sunulduğu konumlarda ilk sırada 547 projeyle İstanbul, ikinci sırada 107 projeyle Ankara, üçüncü sırada 76 projeyle İzmir, dördüncü sırada 58 projeyle Antalya, beşinci sırada ise 29 projeyle Bursa harita üzerinde gösterilmektedir (Şekil 2).

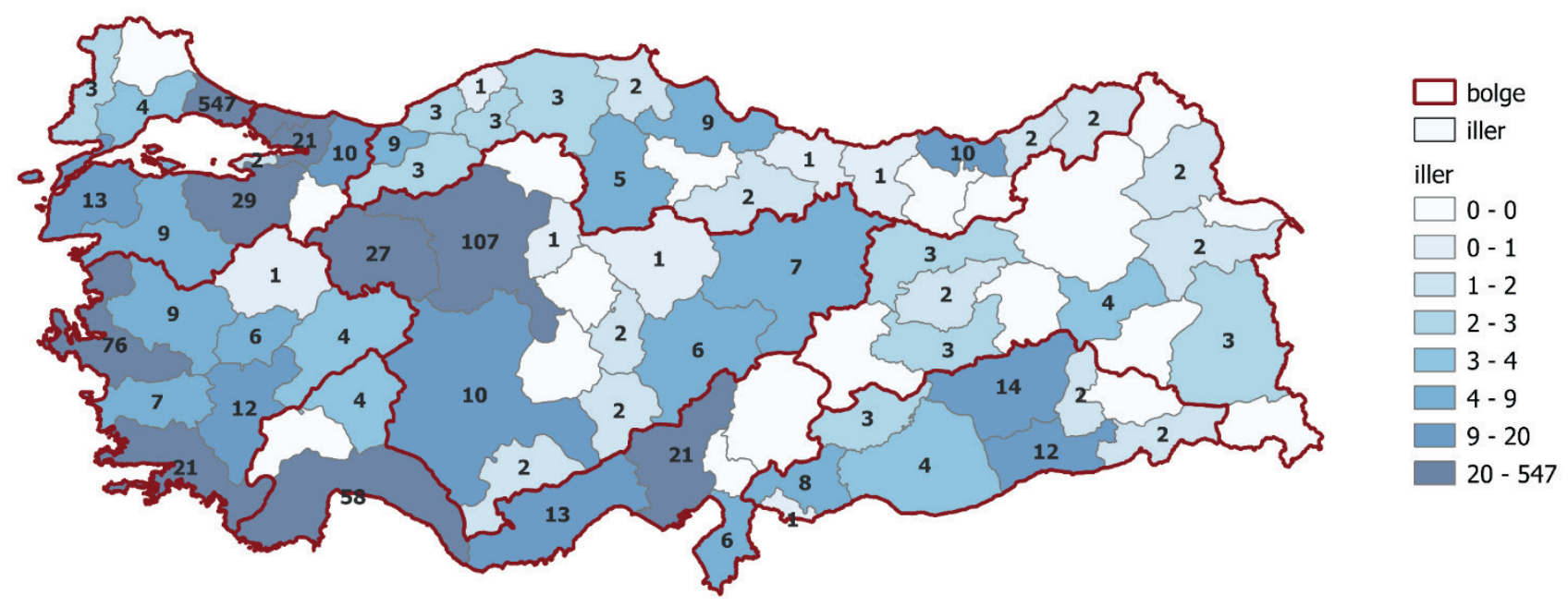

Şekil 2. KF platformlarındaki projelerin Türkiye genelinde illere göre dağılımları 
Tablo 8

Bölgelere göre proje dă̆llımları

\begin{tabular}{|c|c|c|c|c|c|}
\hline Bölge Adı & Başarılı Proje Sayısı & Başarısız Proje Sayısı & Toplam Proje Sayısı & Başarı Oranı & Türkiye Ortalaması \\
\hline Marmara & 193 & 445 & 638 & $\% 30,25$ & Üstünde \\
\hline Ege & 19 & 117 & 136 & $\% 13,97$ & Altında \\
\hline Akdeniz & 26 & 76 & 102 & $\% 25,4$ & Üstünde \\
\hline Karadeniz & 9 & 48 & 57 & $\% 15,78$ & Altında \\
\hline İç Anadolu & 30 & 135 & 165 & $\% 18,18$ & Altında \\
\hline Güneydoğu Anadolu & 11 & 35 & 46 & $\% 23,91$ & Üstünde \\
\hline Doğu Anadolu & 0 & 19 & 19 & 0 & Altında \\
\hline
\end{tabular}

\section{TARTISSMA VE ÖNERILLER}

Ortaya koyulan çalışma Türkiye'deki KF platformlarını daha iyi anlayabilmek, eksikleri tespit etmek ve sorunlar için çözüm önerisi üretmek adına yapılmış en genel kapsamlı çalışmalardan biridir. Bu kapsamda, alternatif fon elde etme aracı olarak KF platformları Türkiye özelinde değerlendirildiğinde elde edilen bulgular geçtiğimiz yıllara göre kıyasla proje sayısının 3-4 kat artmasına rağmen başarı oranının gözle görülür bir biçimde düştüğü göstermektedir (Tablo 9). Benzer sorun yurtdışında faaliyet gösterip çok fazla proje verisine sahip olan Kickstarter ve Indiegogo gibi platformlarda da mevcuttur. Öyle ki, geçtiğimiz yıllarda \%40'n üzerinde proje başarılı bir şekilde fonlanabiliyorken, 2020'de bu oran \%37,44'e düşmüştür (Yeh ve Chen, 2020). Bu sebeple KF platformları için genel bir sorun haline gelen başarı oranını iyileştirmek için literatürde birçok araştırmacının başarıyı tahmin etmeye çalıştı̆̆ı görülmektedir. Fakat çok iyi bir şekilde kurulan modellerin son kullanıcıya yani destekçi veya proje sahibine aktarılamadığı gözlemlenmektedir. Bu nedenle başarılı fonlanan proje sayısı yeterince artmamaktadır.

Tablo 9

Yıllara göre başarı oranlarının karşılaşıtırılması

\begin{tabular}{lcccc}
\hline Çalışma & $\begin{array}{c}\text { İncelenen Platform } \\
\text { Sayısı }\end{array}$ & Proje Sayısı & Yıl & Başarı Oranı \\
\hline (Çubukçu, 2017) & 5 & 485 & 2017 & $\% 30$ \\
(Sakarya ve Bezirgan., 2018) & 3 & 355 & 2018 & $\% 29,18$ \\
Mevcut Çalışma & 6 & 1635 & 2021 & $\% 23,18$ \\
\hline
\end{tabular}

Bu doğrultuda elde ettiğimiz bulgular, gelecek çalışmalarda son kullanıcılara sunulabilecek bir web tabanlı karar destek sisteminin gerekliliğini ortaya koymaktadır. Çünkü destekçiler için yaratılacak kalite sinyali için projenin sahip olduğu öznitelikler önemli bir rol üstlenmektedir. Bu öznitelikler kullanılarak oluşturulacak sistem üzerinde sorgulanan proje özelliklerine göre bir mekanizma sağlanırsa, projelerdeki kalite düzeyi artış göstererek destekçilerin fonlama algısı üzerinde değişiklik yapmasını sağlayacaktır.

Diğer taraftan, Türkiye'deki KF ekosisteminin daha fazla ve hızlı gelişebilmesi için birtakım değişikliklere gereksinim vardır. Çalışmamız kapsamında ortaya koyulan ve KF üzerinde verimliliğin artmasını sağlayabilme potansiyeli olan öneriler şu şekilde sıralanmaktadır;

- KF projelerinin başarısını tahmin etmek için kullanılan faktörler arasında analiz etmesi en zor olan kısım video ve sesle ilgili materyallerdir (Shi ve ark., 2021). Fakat projeleri iyi anlayabilmek için bu faktörlerin göz ardı edilmemesi gerekmektedir. Bu sebeple, video ve sesle ilgili veriler toplandıktan sonra farklı yazılım kütüphaneleri kullanılarak matrislere çevrilip analiz edilebilir. Analizlerle birlikte projede kullanılacak görsellerle ilgili proje sahiplerine karar desteği sağlanabilir.

- KF platformlarının birçoğunda proje oluşturucular ödül gönderimini zamanında yapmamaktadır. KF platformları ise bu noktada sorumluluk kabul etmemektedir. Bu durum, destekçi ya da girişimcilerin KF ile ilgili algılarını olumsuz etkilemektedir. Bu sebeple ödül tabanlı platformlarda ödül gönderimleri bir denetim mekanizmasına tabi tutulmalıdır.

KF platform verileri içerisinde birçok örüntü bulundurmaktadır. Bu örüntülerin daha iyi anlaşılabilmesi için veri madenciliği teknikleri aktif bir şekilde kullanılmalıdır. 
- Platformlara eklenen projeler görevli bir editör kontrolünden geçmelidir. Çünkü bazı platformlarda kitle fonlamasıyla alakası olmayan projeler de yer almaktadır. Örneğin, "hayatımı finanse edin" türündeki projeler (tatile çıkmak, yeni ürün almak, fatura ödemek, askerlik parası toplamak) gibi projelerin sayısı KF kullanım amaçlarını olumsuz etkilemektedir.

Bir KF projesi başlatılırken proje sahibinin karşılaştı̆̆ ana zorluklardan bir tanesi hedef miktar olarak ne kadar para toplanılacağına karar vermektir. Gerçekçi olmayan yüksek bir hedef belirlemek yatırımcıyı ya da destekçiyi caydırabileceğinden dolayı miktarın çok iyi belirlenmesi gerekir. Bu noktada literatürdeki deneysel bulgular da göstermektedir ki; çok yüksek hedefler, başarıyı olumsuz anlamda etkilemektedir (Ralcheva ve Roosenboom, 2020). Bu sebeple bir kullanıcıya proje eklerken web platformu üzerinden ilgili özniteliğin kategoriye göre ortalaması gösterilirse daha gerçekçi hedeflerin ortaya koyulması sağlanacaktır.

Platformlar üzerindeki kategoriler farklı sektörel alanlardaki iş fikirlerinin dahil edilebilmesi için genişletilebilir. Örneğin tarım, otomotiv, kimya ya da yapı gibi kategoriler proje sayısının artmasını sağlayacaktır. Aynı zamanda ana kategorilerin altında alt kategoriler oluşturularak kullanıcılara sunulabilir.

\section{SONUÇ}

Sosyal girişimcilik olarak tanımlanabilecek kitle fonlamasının önemi, COVID-19 pandemi döneminde daha iyi anlaşılmaktadır. Çünkü girişimlerin ya da projelerin fon sağlama süreçlerini web platformları üzerinden yapabilmesi coğrafi engelleri ortadan kaldırmaktadır. Bu kapsamda, dünya genelinde KF platformları üzerinde bir kullanıcı artışı gözlemlenmektedir. Fakat bu artış, beraberinde kalite düzeyinin azalmasına sebep olacak etkenlere sebep olmuştur. Çünkü ilk olarak yatırımcı ve destekçiler yatırım doygunluklarına ulaşmış ve yeni projeler için yeterli finansman sağlanamamıştır. İkinci olarak, platformlardaki proje sayıları geçmiş yıllara göre artı̧̧ göstermiş fakat destekçilere ya da yatırımcılara verilen kalite sinyali düşüş göstermiştir. Üçüncü olarak, kitlelerin sağlayabileceği fonlama gücü hakkında web kullanıcıları henüz yeterli bir bilgiye sahip değildir. Son olarak ise, bir proje ya da kampanyanın vaat ettiği başarının yatırımdan önce ölçülmesini sağlayacak iş zekası temelli bilgi sistemleri henüz oluşturulmamıştır. Bu nedenler, tüm dünyada sosyal ve dijital girişimcilikte elde edilebilecek başarılı işlerin durağanlaşmasına sebep olmaktadır. Ayrıca, KF ile ilgili yapılan yasal düzenlemelerin ve platformların bu düzenlemelere göre entegrasyonunun yavaş ilerlemesi de KF’in Türkiye'de istenilen seviyede olmaması nedenlerinden biridir.

Diğer taraftan, 24-35 yaş grubundaki bireylerin kitle fonlaması kampanyaları için aktif olma olasılıkları çok daha yüksek olarak göze çarpmaktadır (Fundera, 2021). Fakat, Türkiye 24-35 yaş grubundaki nüfus bakımından dünyada 17. sırada olmasına rağmen kitle fonlamasında faaliyet gösteren ülkeler arasında toplanan fon bakımından ilk 30 içerisinde değildir (Crowdfunding Statistics Worldwide Report, 2021). Bu nedenle, 2025 y1lında milyarlarca dolar hacme ulaşması beklenen KF ekosisteminde daha büyük bir pay elde edilebilmesi için Türkiye'deki KF platformlarında hazırlanan proje sayısının, KF bilinirliğinin, başarı oranlarının ve fonlama miktarının artııılması gerekmektedir. Böylece katma değeri yüksek olan projelerin ve iş fikirlerini hayata geçmesi sağlanacaktır.

Sonuç olarak, toplamda 1635 projeden oluşan ve 21 milyon TL büyüklüğe sahip Türkiye KF ekosisteminde \%23,18 başarı yüzdesiyle projeler fonlanmaktadır. İcerik analiziyle sağlanan bulgular, en çok Teknoloji, Kültür-Sanat ve Film-Video-Fotoğraf kategorilerinde proje yayınlandığını göstermektedir. Ayrıca destekçiler beğendikleri bir projenin hayata geçmesi için ortalama 530 TL fon sağlamaktadır ve başarılı proje başına yaklaşık olarak 55.000 TL fon düşmektedir. Bölgesel olarak Marmara, Akdeniz ve Güneydoğu Anadolu fonlama yüzdeleri bakımından en başarılı bölgelerdir.

Gelecek çalışmalarda, KF platformlarında yeni yayınlanarak kampanya süresi bitmiş olan projeler veri setine dahil edilerek içerik analizi güncelleştirilebilir. Ayrıca platformlardaki özniteliklerden başarıya en çok etki eden faktörlerin öznitelik seçim yöntemleriyle bulunmasıyla birlikte KF projelerinin başarı tahmini mekanizması oluşturulabilir. Bu doğrultuda gelecek çalışmalarda, elde edilen veri setiyle birlikte başarıya en çok etki eden faktörler belirlenerek makine öğrenmesi ve iş zekası yöntemleriyle bir karar destek sistemi oluşturulacaktır. Sonrasında ise oluşturulan sistemin etkileri KF paydaşlarıyla görüşülerek test edilecektir. Hedeflenen yapının KF kullanıcılarına sunulmasıyla birlikte proje başarısını ve fonlama ihtimalini arttırma potansiyeli bulunmaktadır. 
Hakem Değerlendirmesi: Dış bağımsız.

Çıkar Çatışması: Yazarlar çıkar çatışması etmemişlerdir

Finansal Destek: Yazarlar bu çalışma için finnansal destek almadığını beyan etmemişlerdir.

Yazar Katkıları: Çalışma Konsepti/Tasarım- M.K.,C.A.; Veri Toplama-M.K.; Veri Analizi/Yorumlama- M.K.,C.A.,Ç.T.; Yazı Taslağı- M.K.; İçeriğin Eleştirel İncelemesi- M.K.,C.A.,Ç.T.; Son Onay ve Sorumluluk- M.K.,C.A.,Ç.T

Peer-review: Externally peer-reviewed.

Conflict of Interest: The authors have no conflict of interest to declare.

Grant Support: The authors declared that this study has received no financial support.

Author Contributions: Conception/Design of Study- M.K.,C.A.; Data Acquisition- M.K.; Data Analysis/Interpretation- M.K.,C.A.,Ç.T.; Drafting Manuscript- M.K.; Critical Revision of Manuscript- M.K.,C.A.,C.T.; Final Approval and Accountability- M.K.,C.A.,Ç.T.

\section{Kaynaklar/References}

Açikgöz, B., Ayanoğlu, Y. ve Yanık, S. S. (2020). Muhasebe bakış açısından bağış (yardım) ve ödüle dayalı kitlesel fonlama. Muhasebe ve Finansman Dergisi, 86, 99-120.

Ahlers, G. K. C., Cumming, D., Gunther, C., \& Schweizer, D. (2015). Signaling in equity crowdfunding. Entrepreneurship Theory and Practice, 39(4), 955-980.

Akyildiz, B. (2021). Gelişmiş ve gelişmekte olan ülkelerdeki kitlesel fonlamanın karşılaştırılması üzerine bir inceleme. (Yüksek Lisans Tezi), Hacettepe Üniversitesi Sosyal Bilimler Enstitüsü, Ankara.

Alazazi, M., Wang, B, \& Allan, T. (2020). Success factors of donation-based crowdfunding campaigns: a machine learning approach. Proceedings of the 53rd Hawaii International Conference on System Sciences, 2507-2516.

Ar1kovan1, (2021, August 16), Retrieved from https://arikovani.com/

Atsan, N. ve Erdoğan, E. O. (2015), Girişimciler için alternatif bir finansman yöntemi: kitlesel fonlama (crowdfunding), Eskişehir Osmangazi Üniversitesi Íktisadi ve İdari Bilimler Dergisi, 10(1), 297-320.

Babich, V., Marinesi, S. \& Tsoukalas, G. (2020), Does crowdfunding benefit entrepreneurs and venture capital investors ?, Manufacturing ve Service Operations Management, 23(2), 1-17.

Belleflamme, P. \& Lambert, T. (2016), An industrial organization framework to understand the strategies of crowdfunding platforms, In International Perspectives on Crowdfunding, Emerald Insight.

Bloomberg, (2021, July 1), Retrieved from https://www.bloomberght.com/kitle-fonlamasina-yatirimcidan-rekor-talep-2281097

Borrero-Dominguez, C., Cordón-Lagares, E. \& Hernández-Garrido, R. (2020), Analysis of success factors in crowdfunding projects based on rewards: a way to obtain financing for socially committed projects. Heliyon, 6(4), 1-9.

Buluşum, (2021, August 14), Retrieved from https://www.bulusum.biz/

Chang, J. (2021, August 3), 80 crowdfunding statistics you must see: 2021 platforms, impact ve campaign data, finances online reviews for business. Retrieved From https://alternatives.financesonline.com/crowdfunding-statistics/\#1

Çonkar, M. K. ve Canbaz, M. F. (2018), Kitle fonlaması finansman yöntemi: türkiye'de sistemin geliştirilmesine yönelik öneriler, Optimum Ekonomi ve Yönetim Bilimleri Dergisi, 5(2), 119-132.

Crowdfon, (2021, August 3), Retrieved from https://www.crowdfon.com/

Crowdfunding Statistics Worldwide Report, (2021, July 9), Retrieved From https://p2pmarketdata.com/crowdfunding-statistics-worldwide/

Çubukçu, C. (2017), Kitlesel Fonlama : Türkiye'deki kitlesel fonlama platformları üzerinden bir değerlendirme, Girişimcilik ve İnovasyon Yönetimi Dergisi, 6(2), 155-172.

Cumming, D., Meoli, M. \& Vismara, S. (2021), Does equity crowdfunding democratize entrepreneurial finance?, Small Business Economics, 56(2), $533-552$.

Du, Q., Li, J., Du, Y., Wang, G. A. \& Fan, W. (2021), Predicting crowdfunding project success based on backers' language preferences. Journal of the Association for Information Science and Technology, 1-17.

Farhoud, M., Shah, S., Stenholm, P., Kibler, E., Renko, M. \& Terjesen, S. (2021), Social enterprise crowdfunding in an acute crisis. Journal of Business Venturing Insights, 15, 1-6.

Fonbulucu, (2021, June 4), Retrieved from https://fonbulucu.com/

Fongogo, (2021, June 4), Retrieved from https://fongogo.com/

Frydrych, D., Bock, A. J., Kinder, T. \& Koeck, B. (2014), Exploring entrepreneurial legitimacy in reward-based crowdfunding, Venture Capital, 16(3), $247-269$.

Fundera, (2021, June 5), Crowdfunding statistics, Retrieved from https://www.fundera.com/resources/crowdfunding-statistics

Gago, U. ve Zeytinler, E. G. (2020, June 4), Borçlanmaya dayalı kitle fonlaması, Retrieved from https://www.gsghukuk.com/tr/bultenler-yayinlar/makaleyazilar/borclanmaya-dayali-kitle-fonlamasi.html

Greenberg, M. D., Pardo, B., Hariharan, K. \& Gerber, E. (2013), Crowdfunding support tools: predicting success ve failure. CHI '13 Extended Abstracts on Human Factors in Computing Systems, 1815-1820. 
Gürler, C. \& Çağlar, M. (2021), Success prediction of a crowdfunding project in art categories, Crowdfunding in the Public Sector, Springer. Ideanest, (2021, August 4), Retrieved from https://www.ideanest.org/

İzmirli Ata, F. (2018), Yeni nesil finansman yöntemi olarak kitle fonlama: türkiye potansiyeli, Manisa Celal Bayar Üniversitesi Sosyal Bilimler Dergisi, $16(2), 273-296$.

Jhaveri, S., Khedkar, I., Kantharia, Y. \& Jaswal, S. (2019), Success prediction using random forest, catboost, xgboost and adaboost for kickstarter campaigns, Proceedings of the 3rd International Conference on Computing Methodologies and Communication, 1170-1173.

Kayhan, S. (2017), Fongogo: A case study on the usability of the local crowdfunding and fundraising websites in turkey, Uluslararast Sosyal Bilimler Dergisi, 5(9), 95-105.

Koch, J.-A. \& Siering, M. (2015), Crowdfunding success factors : the characteristics of successfully. European Conference on Information Systems Proceedings, $1-15$.

Kromidha, E. \& Robson, P. (2016), Social identity and signalling success factors in online crowdfunding, Entrepreneurship and Regional Development, 28(9-10), 605-629.

Li, Y., Rakesh, V. \& Reddy, C. K. (2016), Project success prediction in crowdfunding environments, Proceedings of the 9th ACM International Conference on Web Search and Data Mining, 247-256.

Lukkarinen, A., Teich, J. E., Wallenius, H. \& Wallenius, J. (2016), Success drivers of online equity crowdfunding campaigns, Decision Support Systems, $87,26-38$.

Mollick, E. (2014), The dynamics of crowdfunding: an exploratory study, Journal of Business Venturing, 29(1), 1-16.

Moysidou, K. \& Hausberg, J. P. (2020), In crowdfunding we trust: a trust-building model in lending crowdfunding, Journal of Small Business Management, 58(3), 511-543.

Orçun, Ç. ve Boran Sezgin, O. (2020), Ödül temelli kitle fonlama projesi için kritik başarı faktörleri. Proceedings 19th International Business Congress, 668-676.

Petruzzelli, A. M., Natalicchio, A., Pannielo, U. \& Roma, P. (2019), Understanding the crowdfunding phenomenon and its implications for sustainability, Technological Forecasting ve Social Change, 141, 138-148.

Ralcheva, A. \& Roosenboom, P. (2020), Forecasting success in equity crowdfunding, Small Business Economics, 55(1), $39-56$.

Ryoba, M. J., Qu, S. \& Zhou, Y. (2020), Feature subset selection for predicting the success of crowdfunding project campaigns, Electronic Markets, 1-14.

Sakarya, Ş. ve Bezirgan, E. (2018), Kitlesel fonlama platformları: türkiye ve yurtdıșı karşılaştırması, Düzce Üniversitesi Sosyal Bilimler Enstitüsü Dergisi, 8(2), 18-33.

Shi, J., Yang, K., XU, W. \& Wang, M. (2021), Leveraging deep learning with audio analytics to predict the success of crowdfunding projects, Journal of Supercomputing, 1-21.

Shneor, R. \& Vik, A. A. (2020), Crowdfunding success: a systematic literature review 2010-2017, In Baltic Journal of Management, 15(2), 149-182.

Sidiq, R. S. S., Jalil, A., Willya, R. \& Achmad, W. (2021), Virtual world solidarity: how social solidarity is built on the crowdfunding platform kitabisa. com, Webology, 18(1), 192-202.

Valančienè, L. \& Jegelevičiute, S. (2013), Valuation of crowdfunding: benefits and drawbacks, economics and management, 18(1), $39-48$.

Walthoff-Borm, X., Schwienbacher, A. \& Vanacker, T. (2018), Equity crowdfunding: first resort or last resort?, Journal of Business Venturing, 33(4), $513-533$.

Wang, W., Zheng, H. \& Wu, Y. J. (2020), Prediction of fundraising outcomes for crowdfunding projects based on deep learning: a multimodel comparative study, Soft Computing, 24(11), 8323-8341.

Xiao, Y., Liu, C., Zheng, W., Wang, H. \& Hsu, C. H. (2021), A feature interaction learning approach for crowdfunding project recommendation. Applied Soft Computing, 112, 1-8.

Yeh, J. Y. \& Chen, C. H. (2020), A machine learning approach to predict the success of crowdfunding fintech project. Journal of Enterprise Information Management, 107, 1-19.

Yuan, H., Lau, R. Y. K. \& Xu, W. (2016), The determinants of crowdfunding success: a semantic text analytics approach, Decision Support Systems, 91, $67-76$.

Zengin, S., Yüksel, S. ve Kartal, M. T. (2017), Kitle fonlaması sisteminin türkiye’ye faydaları, bankacılık ve sermaye piyasası araştırmaları dergisi, 1(2), $22-32$.

Zhou, M. J., Lu, B., Fan, W. P. \& Wang, G. A. (2018), Project description and crowdfunding success: an exploratory study, Information Systems Frontiers, 20(2), 259-274. 
